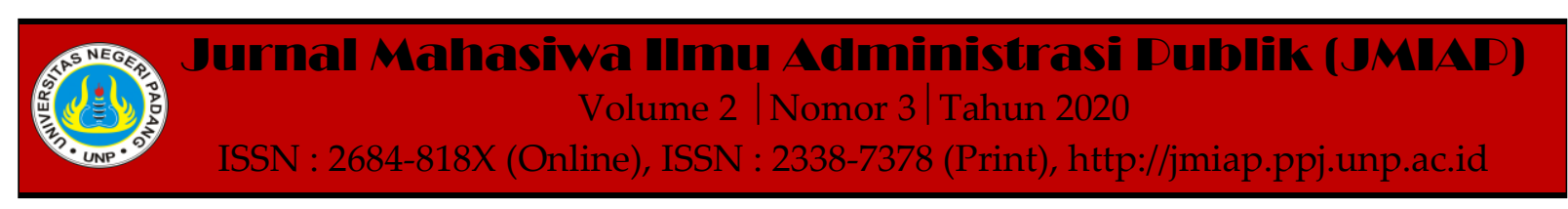

\title{
IMPLEMENTASI KEBIJAKAN PENERIMAAN PESERTA DIDIK BARU DENGAN SISTEM ZONASI PADA SMP NEGERI DI KOTA PADANG
}

\author{
Meylan Siswara Handani ${ }^{1(a)}$, Aldri Frinaldi ${ }^{\text {(b) }}$ \\ ${ }^{1}$ Jurusan Ilmu Administrasi Negara, Universitas Negeri Padang \\ ${ }^{2}$ Jurusan Ilmu Administrasi Negara, Universitas Negeri Padang \\ a)meylansiswara15@gmail.com, ${ }^{b)}$ aldri@fis.unp.ac.id
}

\begin{abstract}
This study aimed to analyze the implementation of policies in the New Student Admissions (PPDB) using the zoning system at State Junior High Schools in Padang City. This was a qualitative research using descriptive methods. Informants in this study were selected based on certain criteria using a purposive sampling technique. Data collection techniques used in this study were interviews and documentation. The data in this study were analyzed with interactive analysis model. Based on the results of this study and discussion, the implementation of policies in PPDB using the zoning system at State Junior High Schools in Padang City could be said to be quite good. However, there were several inhibiting factors, namely, the emergence of interpretation among the community, the lack of support and misunderstanding of the community; The tiered socialization system implemented by the Education Office was not maximal; and the time for the issuance of the technical instructions which was close to the time of PPDB implementation so that the socialization is not optimal.
\end{abstract}

Keywords : Implementation, Policy, New Student Admissions, Zoning System

Corresponding author. Email.meylansiswara15@gmail.com,aldri@fis.unp.ac.id

How to cite this article. Handani, M. Siswara \& Frinaldi, A. (2020). Implementasi Kebijakan Penerimaan Peserta Didik Baru dengan Sistem Zonasi pada SMP Negeri di Kota Padang. Jurnal Mahasiwa Ilmu Administrasi Publik (JMIAP) Jurusan Ilmu Administrasi Negara Fakultas Ilmu Sosial Universitas Negeri Padang, Volume 2 (3), Hal. 73-86.

http://jmiap.ppj.unp.ac.id

ISSN : 2684-818X (Online), ISSN : 2338-7378 (Print)

Copyright@2020. Published by Labor Jurusan Ilmu Administrasi Negara FIS UNP, Padang 


\section{PENDAHULUAN}

Dalam Permendikbud No. 51 Tahun 2018 terdapat peraturan tentang diterapkannya sistem zonasi sebagai salah satu jalur dalam PPDB. Dalam Permendikbud Nomor 51 Tahun 2018 Pasal 16 ayat (2) dinyatakan bahwa jalur zonasi paling sedikit $90 \%$ dari daya tampung sekolah. Pada Pasal 2 dinyatakan bahwa sasaran dari penerimaan peserta didik baru adalah pelaksanaan PPDB yang dilaksanakan dengan nondiskriminatif, objektif, transparan, dan berkeadilan.

Menurut Muhadjir Effendy dilansir dari kompas.com (2018) diambilnya kebijakan terkait zonasi adalah sebagai respon atas adanya kastanisasi dan favoritisme pada sistem pendidikan yang sejauh ini ada disebabkan karena diadakannya seleksi kualitas bagi calon peserta didik dalam PPDB. Diharapkan atas adanya kebijakan ini, PPDB dapat terlaksana tanpa adanya diskriminasi. Selain itu juga agar mampu dalam memberikan kesempatan yang sama untuk setiap calon peserta didik dalam memperoleh pendidikan, sehingga diperoleh kualitas pendidikan yang dapat menghasilkan peserta didik berprestasi.

Penerapan sistem zonasi sudah diberlakukan pada beberapa daerah di Indonesia. Salah satunya adalah Kota Padang yang sudah melaksanakan PPDB dengan menggunakan sistem zonasi sejak tahun 2018.

Sejak 2007, sistem dalam PPDB pada SMP Negeri sudah dilaksanakan secara online dan sudah menggunakan sistem rayon sekolah. Artinya zona wilayah untuk sekolah siswa sudah ditentukan. Namun sebelum adanya sistem zonasi, PPDB secara mandiri dari sekolah masih diperbolehkan. Artinya sekolah diperbolehkan membuka jalur khusus, seperti tes untuk masuk ke sekolah tersebut. Biasanya sekolah yang dianggap 'favorit' yang membukan jalur mandiri tersebut. Sejak adanya sistem zonasi, tidak ada lagi PPDB yang dibuka secara mandiri. PPDB pada SD dan SMP dilaksanakan secara online, dan zonanya sudah ditentukan. Untuk SD berdasarkan daerah tempat tinggal, dan untuk SMP berdasarkan daerah SD asal.

Pada tahun 2019, Kota Padang telah melaksanakan PPDB dengan sistem zonasi pada SD, SMP dan SMA/SMK di seluruh Kota Padang. Untuk SD dan SMP pelaksanaannya berpedoman kepada Perwako Padang No. 32 Tahun 2019 Tentang Tata Cara Pelaksanaan Penerimaan Peserta Didik Baru. Pada Pasal 2 tertuang tujuan adanya peraturan walikota ini adalah agar PPDB berjalan secara objektif, akuntabel, transparan, dan tanpa diskriminasi sehingga mendorong peningkatan akses layanan dan pemerataan mutu pendidikan.

Namun ternyata dalam implementasinya, PPDB di Kota Padang masih mengalami sejumlah permasalahan. Hal ini dapat dilihan dari adanya laporanlaporan yang dilayangkan ke Ombudsman RI Perwakilan Provinsi Sumatera Barat terkait PPDB tahun 2019.

Laporan dari masyarakat terkait PPDB dari tahun 2017 hingga 2019 terus meningkat. Hal ini ditinjau dari tabel sebagai berikut:

Tabe 1. Jumlah Laporan Masyarakat Terkait Penyimpangan Prosedur PPDB Tahun 2017-2019

\begin{tabular}{ccccccc}
\hline Tahun & Laporan & \multicolumn{5}{c}{ Jumlah Laporan Terkait PPDB } \\
& $\begin{array}{c}\text { Kota Padang } \\
\text { Terkait PPDB }\end{array}$ & SD & SMP & MTSN & SMA & Kabupaten/Kota \\
2017 & 4 & 1 & 0 & 0 & 1 & 2 \\
2018 & 9 & 3 & 1 & 1 & 2 & 2 \\
2019 & 23 & 0 & 17 & 1 & 3 & 2 \\
\hline
\end{tabular}

Sumber : Ombudsman RI Perwakilan Sumatera Barat 2019

74 | Jurnal Mahasiwa Ilmu Administrasi Publik | Volume 2 | Nomor 3 | Tahun 2020 | (Hal. 73-86) 
Berdasarkan tabel di atas dapat diketahui bahwa jumlah laporan terkait PPDB dari tahun-ketahun terus mengalami pengingkatan, dan laporan dari kota Padang adalah pelaporan yang mendominasi. Dibandingkan dengan tahun-tahun sebelumnya, laporan terkait PPDB pada tahun 2019 adalah yang paling dominan.

Terdapat 17 laporan untuk 17 SMP Negeri, 3 diantaranya adalah laporan yang melaporkan dua sekolah sekaligus. Dari 17 laporan untuk SMP yang ada di tahun 2019, SMP yang memperoleh laporan lebih dominan dari SMP yang lain adalah SMPN 17 Padang, SMPN 25 Padang, dan SMPN 31 Padang yang memperoleh laporan sebanyak $\geq 2$ laporan.

Dari latar belakang yang telah dijelaskan di atas, tujuan yang hendak dicapai dari penelitian ini adalah untuk mengetahui Implementasi Kebijakan dalam PPDB dengan sistem zonasi pada SMP Negeri di Kota Padang tahun 2019, dan mengidentifikasi faktor penghambat implementasi kebijakan.

\section{TINJAUAN PUSTAKA}

\section{Implementasi Kebijakan Publik}

Menurut Aldri, dkk (2011:11) kebijakan adalah strategi dan tindakan dalam rangka pencapaian tujuan yang diinginkan sebagai upaya pemecahan suatu masalah. Sri (2014:1.6) juga mengemuka- kan hal-hal yang terkandung dalam kebijakan diantaranya adalah tujuan yang ingin dicapai yang berpihak kepada kepentingan masyarakat.

Eko (2012:1) menyatakan bahwa kebijakan mempunyai unsur-unsur yang memberikan pemahaman tentang alasan mengapa kebijakan tersebut perlu untuk ada. Salah satu unsur terpenting dari kebijakan adalah tujuan kebijakan.

Dengan meninjau dari pengertianpengertian di atas maka dapat ditarik benang merah bahwa implementasi kebijakan adalah sebuah kegiatan dalam rangka melaksanakan kebijakan dengan strategi implementasi kebijakan yang dikaitkan dengan berbagai lapisan masyarakat selaku kelompok sasaran.

Menurut Nico (2007:20-21) tiap-tiap kebijakan yang diterbitkan oleh pelaksana kebijakan harus memberikan kesempatan yang luas bagi masyarakat untuk ikut berpartisipasi, dengan memberikan akses secara terbuka terhadap kebijakan tersebut.

Siswanto, dkk. (2016:53) juga mengemukakan bahwa transparansi dalam suatu kebijakan adalah dasar yang dapat menjamin keleluasaan bagi seluruh masyarakat dalam rangka mendapatkan informasi yang berkaitan dengan pelaksanaan pemerintahan, juga keterbukaan implementor dalam menciptakan kebijakan.

Selanjutnya George Edward III dalam Deddy Mulyadi (2016:70) apa yang menjadi tujuan dan sasaran kebijakan harus disampaikan kepada kelompok sasaran sehingga akan mengurangi penyimpangan dalam implementasi. Tujuan dan sasaran yang tidak jelas bahkan tidak diketahui sedikitpun oleh kelompok sasaran, dapat menimbulkan resistensi dari kelompok sasaran.

Penelitian terdahulu dari penelitian ini diantaranya penelitian Khairunisa Adinda dan Suyato (2019) yang meneliti tentang Dampak Kebijakan Zonasi pada Penerimaan Peserta Didik Baru. Dari penelitian ini didapat hasil bahwa sosialisasi sistem zonasi yang mendekati hari pelaksanaan PPDB menyebabkan kurangnya pemahaman dan membuat orang tua calon peserta didik bingung. Seterusnya sistem zonasi belum dapat merubah pola pikir orang tua yang menginginkan anaknya bersekolah di sekolah favorit atau unggulan.

Penelitian selanjutnya adalah penelitian Umi Latifatul Khasanah (2018) yang meneliti tentang Analisis Implementasi Kebijakan Sistem Zonasi Perspektif Stakeholder Sekolah. Dari penelitian ini didapat hasil bahwa kritik terhadap kebijakan sistem zonasi adalah terbatasnya pilihan sekolah bagi calon peserta didik. 
Dalam penelitian ini peneliti mengadopsi model implementasi menurut Van Meter dan Van Horn dalam Deddy Mulyadi (2016:72) yang mengemukakan bahwa terdapat 6 hal yang mempengaruhi suatu implementasi kebijakan, di antaranya:

1. Standar dan sasaran kebijakan Agar interpretasi yang menyebabkan konflik antar implementor tidak timbul, maka suatu kebijakan harus terukur dan jelas.

2. Sumber daya

Suatu kebijakan memerlukan dukungan dari sumber daya, yakni sumber daya manusia, juga sumber daya bukan manusia.

3. Komunikasi antar organisasi dan penguatan aktivitas

Implementasi suatu kebijakan kerap kali perlu untuk dikoordinasikan dengan instansi-instansi lain untuk mencapai keberhasilan yang diinginkan.

4. Karakteristik agen pelaksana

Yakni sejauhmana para kelompok yang berkepentingan melimpahkan dukungannya untuk pelaksanaan suatu kebijakan, juga karakter implementor yaitu menolak atau mendukung kebijakan, dan seperti apa bentuk opini masyarakat apakah mendukung atau menolak pelaksanaan kebijakan.

5. Kondisi sosial, ekonomi dan politik Mencakup keadaan sosial, ekonomi dan politik yang bisa mendorong keberhasilan dalam pelaksanaan suatu kebijakan.

6. Disposisi Implementor

Dalam hal ini melingkup 3 hal, yaitu:

a. Tanggapan para pelaksana akan adanya suatu kebijakan. Hal ini dapat mempengaruhi keinginannya dalam mengimplementasikan suatu kebijakan;

b. Kognisi, yaitu pengetahuan atau pemahaman implementor akan kebijakan; c. Intensitas disposisi implementor, yaitu kecenderungan atau preferensi suatu nilai dari implementor kebijakan.

\section{PPDB dengan Menggunakan Sistem Zonasi}

Kebijakan mengenai penerimaan peserta didik baru untuk tahun ajaran 2019/2020 juga penjelasan terkait sistem zonasi tertuang dalam Permendikbud Nomor 51 Tahun 2018. Pada Pasal 3 poin b Permendikbud Nomor 51 Tahun 2018 dinyatakan bahwa peraturan menteri tersebut adalah standar yang digunakan sebagai pedoman bagi kepala daerah untuk membuat kebijakan teknis pelaksanaan PPDB dan menetapkan zonasi sesuai dengan kewenangannya, dan pedoman bagi kepala sekolah dalam melaksanakan PPDB.

Pada Pasal 42 juga dinyatakan bahwa kebijakan atau peraturan daerah dalam pelaksanaan PPDB wajib berpedoman pada permendikbud tersebut. Selanjutnya pada Pasal 2 dinyatakan bahwa sasaran dari penerimaan peserta didik baru pada Permendikbud tersebut adalah pelaksanaan PPDB yang dilaksanakan dengan nondiskriminatif, objektif, transparan, dan berkeadilan.

Pada Pasal 16 ayat (2) dinyatakan bahwa jalur zonasi paling sedikit $90 \%$ dari daya tampung sekolah, dan di ayat (3) dikatakan bahwa jalus prestasi paling banyak 5\% dari daya tampung sekolah. Pasal 26 ayat (1) Seleksi calon peserta didik baru kelas 7 (tujuh) SMP yang menggunakan mekanisme daring dilakukan dengan memprioritaskan jarak tempat tinggal terdekat ke sekolah dalam zonasi yang ditetapkan.

Terkait aturan mengenai sumber daya anggaran tertuang pada pasal 33 ayat (1) yang menyatakan bahwa pelaksanaan PPDB pada sekolah yang menerima bantuan operasional sekolah (BOS) tidak dipungut biaya. Di samping hal itu, komunikasi dan koordinasi juga diatur dalam peraturan ini yang tertuang dalam 
pasal 39 ayat (1) yang mana Dinas Pendidikan provinsi atau kabupaten/kota melakukan koordinasi, pemantauan, dan evaluasi pelaksanaan PPDB.

Selain koordinasi pada Dinas Pendidikan, sosialisasi dan pembinaan kepada kepala sekolah dan masyarakat juga diatur dalam Permendikbud ini dan tertuang dalam Pasal 40 poin a yang mana pemerintah daerah melakukan pembinaan dan pengawasan kepada sekolah yang diselenggarakan oleh pemerintah daerah dan masyarakat di wilayahnya.

Selanjutnya untuk Kota Padang pelaksanaan PPDB pada SD dan SMP berpedoman kepada Peraturan Walikota Padang Nomor 32 Tahun 2019. Pada Pasal 2 dijelaskan bahwa tujuan peraturan walikota ini adalah agar PPDB berjalan secara objektif, akuntabel, transparan, dan tanpa diskriminasi sehingga mendorong peningkatan akses layanan dan pemerataan mutu pendidikan.

Berhubung pada Pasal 19 dinyatakan bahwa tempat pendaftaran bagi calon peserta didik baru SMP Negeri melalui mekanisme dalam jaringan dilakukan di salah satu SMP Negeri di daerah yang terhubung dengan internet, maka diperlukan sumber daya pendukung seperti hardware dan softwate penunjang untuk mengakses internet. Seterusnya terkait sumber daya anggaran tertuang dalam Pasal 28 yang menyatakan bahwa biaya dalam pelaksanaan PPDB dan pendataan ulang pada sekolah yang menerima Bantuan Operasional Sekolah (BOS) dibebankan kepada BOS.

Mengenai penyampaian informasi, pada Pasal 4 ayat (2) diatur bahwa pengumuman pendaftaran penerimaan calon peserta didik baru dilaksanakan melalui papan pengumuman sekolah maupun media lainnya. Seterusnya pada Pasal 5 ayat (2) PPDB dalam jaringan dilakukan melalui laman PSB.diknaspadang.id Mengenai pelaksanaan PPDB dengan mekanisme dalam jaringan dilakukan.
Selanjuntya Penjelasan mengenai ketentuan dalam PPDB sistem zonasi pada SMP Negeri pada peraturan tersebut dapat disimpulkan sebagai berikut.

1. PPDB dilaksanakan mulai dari bulan mei untuk tiap tahunnya.

2. Pengumuman PPDB dilaksanakan melalui papan pengumuman sekolah maupun media lainnya.

3. Kuota untuk jalur zonasi minimal yaitu 90\% dari daya tampung sekolah, termasuk bagi calon peserta didik baru yang berasal dari keluarga yang kurang mampu.

4. Pada jalur zonasi, peserta didik diterima melalui mekanisme daring/online.

5. Tempat pendaftaran melalui mekanisme daring dilakukan di salah satu SMP negeri di daerah yang terhubung dengan jaringan internet.

6. Pendaftaran dengan menggunakan sistem zonasi dilaksanakan dengan memberikan dua pilihan sekolah, pilihan pertama harus SMP dalam zona yang bersangkutan.

7. Pendaftaran dilaksanakan dengan mengisi formulir yang diunduh di web PSB.diknaspadang.id dan diserahkan dengan menyertakan kelengkapan persyaratan yang telah ditentukan.

8. Seleksi untuk jalur zonasi dilaksanakan berdasarkan
a. nilai UASBN dengan ditetapkan. memprioritaskan zonasi yang telah
b. Apabila nilai UASBN dan zonasi sama maka diprioritaskan umur yang lebih tua.
c. Apabila ketentuan yang dimaksud pada poin a dan b sama maka diprioritaskan yang mendaftar lebih awal.

9. Biaya untuk implementasi PPDB dibebankan kepada dana BOS (Bantuan Operasional Sekolah). 


\section{Faktor Penghambat Implementasi Kebijakan}

Berdasarkan pendapat Bambang Sunggono, (1994:149-153) terdapat 4 faktor penghambat dalam implementasi kebijakan, di antaranya :

1. Isi kebijakan

Pertama, belum jelasnya isi suatu kebijakan, dapat menyebabkan gagalnya pelaksanaan suatu kebijakan, artinya tujuan tidak cukup rinci.

Selanjutnya, kekurangan terkait sumber daya pembantu menjadi penyebab kegagalan pada implementasi suatu kebijakan. Contohnya, hal-hal yang terkait dengan tenaga, waktu, dan biaya.

2. Informasi

Dalam pelaksanaan suatu kebijakan, seharusnya implementor yang terlibat memiliki informasi yang berkaitan dengan kebijakan dalam rangka berperan dalam implementasi kebijakan dengan baik, namun pada kenyataannya informasi tersebut tidak ada. Contohnya, dikarenakan terdapatnya gangguan komunikasi.

3. Dukungan

Pengimplementasian kebijakan yang tidak cukup memiliki dukungan akan menyebabkan kebijakan sulit untuk terimplementasikan.

4. Pembagian potensi

Penyebab yang berkenaan pada tidak tercapainya suatu implementasi kebijakan ditentukan juga oleh unsur pembagian potensi di antara imlementor kebijakan. Pada keadaan ini, berkenaan dengan diferensiasi wewenang dan tanggungjawab implementor. Struktur organisasi implementor bisa menyebabkan timbulnya masalah jika dalam pembagian tanggungjawab dan wewenangnya tidak terlalu disesuaikan pada pembagian tugas, juga kurangjelasnya pembatasan.

\section{METODE PENELITIAN}

Pada penelitian ini jenis yang digunakan adalah penelitian kualitatif dengan metode deskriptif, yang berfokus pada implementasi kebijakan dalam PPDB dengan sistem zonasi pada SMP Negeri di Kota Padang, dan faktor-faktor yang menghambat implementasi kebijakan untuk tahun pelajaran 2019/2020. Berdasarkan judul penelitian ini maka penelitian ini dilaksanakan di Kota Padang, khususnya pada Dinas Pendidikan Kota Padang, SMPN 17 Padang, SMPN 25 Padang, dan SMPN 31 Padang. Informan penelitian dipilih berdasarkan kriteria tertentu menggunakan teknik purposive sampling, di antaranya Kepala UPTD Dapodik dan TI Dinas Pendidikan Kota Padang dan Pelaksana PPDB dengan menggunakan sistem zonasi di ketiga sekolah yang menadi lokasi penelitian.

Jenis dan sumber data yang penulis gunakan pada penelitian ini yaitu data primer dan sekunder. Untuk teknik pengumpulan data yang digunakan yaitu wawancara dan dokumentasi. Analisis data pada penelitian ini menggunakan model analisis interaktif. Teknik yang digunakan peneliti adalah teknik Triangulasi Sumber. Proses pengumpulan serta analisis data dilaksanakan dengan melalui langkah reduksi data, penyajian data dan penarikan kesimpulan.

\section{HASIL DAN PEMBAHASAN Implementasi Kebijakan Penerimaan Peserta Didik Baru dengan Sistem Zonasi}

Sebagaimana telah diuraikan sebelumnya bahwa dalam mengukur implementasi kebijakan penerimaan peserta didik baru dengan sistem zonasi penulis menggunakan model implementasi menurut Van Meter dan Van Horn dalam Deddy Mulyadi (2016:72) diantaranya (1) standar dan sasaran kebijakan; (2) sumber daya; (3) komunikasi dan koordinasi antar organisasi dan penguatan aktivitas; (4) karakteristik agen pelaksana; (5) kondisi sosial, ekonomi dan politik; dan (6) disposisi implementor. 
1) Standar dan Sasaran Kebijakan

Berdasarkan temuan peneliti dari hasil wawancara yang dilakukan pada Juni 2020, standar pelaksanaan kebijakan dalam PPDB dengan sistem zonasi pada SMP Negeri di kota Padang berpedoman kepada Permendikbud, yang kemudian diturunkan ke dalam bentuk Perwako, selanjutnya di turunkan lagi menjadi Keputusan Walikota Padang. Temuan tersebut sesuai dengan Pasal 3 poin b dan Pasal 42 Permendikbud Nomor 51 Tahun 2018.

Perwako sebagai standar pelaksanaan yang diturunkan Dinas Pendidikan disusun dengan mengacu kepada Permendikbud No. 51 Tahun 2018. Namun tidak seluruhnya dari Permendikbud tersebut diterapkan di Kota Padang. Ada modifikasi-modifikasi yang dilakukan dengan menyesuaikan kepada situasi dan kondisi daerah. (hasil wawancara, Juni 2020)

Berdasarkan temuan peneliti dari hasil wawancara yang dilakukan pada Juni 2020, sasaran kebijakan sebagai tujuan dari implementasi kebijakan ini adalah terjadinya pemerataan pendidikan, penghapusan kastanisasi dan favoritisme, tidak ada diskriminasi, diberikannya kesempatan yang sama untuk tiap peserta didik dalam rangka memperoleh pendidikan, sehingga diperoleh kualitas pendidikan yang dapat menghasilkan peserta didik yang berprestasi. Hal tersebut sesuai dengan Permendikbud Nomor 51 Tahun 2018 Pasal 2 dan Perwako Padang Nomor 32 Tahun 2019 Pasal 2.

Selain sesuai dengan Permendikbud dan Perwako, temuan di atas juga didukung oleh pendapat Sri $\quad(2014: 1.6) \quad$ yang mengemukakan bahwa hal-hal yang terkandung dalam kebijakan diantaranya adalah tujuan yang ingin dicapai yang berpihak kepada kepentingan masyarakat. Eko (2012:1) juga menyatakan bahwa kebijakan mempunyai unsur-unsur yang memberikan pemahaman tentang alasan mengapa kebijakan tersebut perlu untuk ada. Salah satu unsur terpenting dari kebijakan adalah tujuan kebijakan.
Temuan peneliti memberikan petunjuk bahwa bagi implementor, standar juga sasaran implementasi kebijakan cukup jelas, terukur, serta dapat dipahami para implementor kebijakan. Sehingga tidak menyebabkan konflik antar implementor kebijakan. (hasil wawancara, Juni 2020).

Temuan ini didukung oleh pendapat Van Meter dan Van Horn dalam Deddy Mulyadi (2016:72) yang menyatakan bahwa agar interpretasi yang menyebabkan konflik antar implementor tidak timbul, maka suatu kebijakan harus terukur dan jelas.

\section{2) Sumber Daya}

Keberadaan sumber daya penting untuk mendukung kebjakan, di antaranya sumber daya manusia juga sumber daya non manusia. Sebagaimana pendapat Van Meter dan Van Horn dalam Deddy Mulyadi (2016:72) yang menyatakan jika suatu kebijakan memerlukan dukungan dari sumber daya, yakni sumber daya manusia, juga sumber daya bukan manusia.

Pada kebijakan PPDB dengan sistem zonasi untuk SMP Negeri di Kota Padang tahun 2019, peneliti menemukan jika terdapat sumber daya manusia yakni aktor yang terlibat dalam implementasi kebijakan yang mencakup kewenangan/kehalian para implementor kebijakan, dan sumber daya non manusia yang berupa sarana prasarana maupun anggaran dalam rangka mendukung implementasi kebijakan. (hasil wawancara, Juni 2020).

Selain Dinas Pendidikan Kota Padang, sekolah juga memiliki peran penting. Begitupun dengan masyarakat yang berlaku sebagai golongan yang juga terlibat langsung dalam implementasi PPDB. Jumlah staf yang terlibat pada Dinas pendidikan kurang lebih sekitar 30 orang, dan untuk sekolah sekitar 12 sampai dengan 15 orang. (hasil wawancara, Juni 2020).

Berhubung PPDB dengan sistem zonasi di kota Padang pada SMP negeri dilaksanakan secara online maka terdapat beberapa sumber daya yang diperlukan diantaranya komputer dan segala perangkat 
hardware dan software nya, juga server dan jaringan internet. Selanjutnya terkait sumber daya anggaran pada pelaksanaan kebijakan berasal dari dana BOS, hal ini sesuai dengan Permendikbud Nomor 51 Tahun 2018 pasal 33 ayat (1) dan sesuai dengan Peraturan Walikota Nomor 32 Tahun 2019 Pasal 28.

\section{3) Komunikasi Antar Organisasi dan Penguatan Aktivitas}

Berdasarkan temuan peneliti dari hasil wawancara yang dilakukan pada Juni 2020, Dinas Pendidikan Kota Padang melakukan koordinasi dalam implementasi kebijakan. Hal ini sesuai dengan Permendikbud Nomor 51 Tahun 2018 pasal 39 ayat (1). Temuan tersebut juga didukung oleh pemaparan Van Meter dan Van Horn dalam Deddy Mulyadi (2016:72) yang menyatakan jika implementasi suatu kebijakan kerap kali perlu untuk dikoordinasikan dengan instansi-instansi lain untuk mencapai keberhasilan yang diinginkan.

Implementasi kebijakan dalam PPDB dengan menggunakan sistem zonasi di Kota Padang melibatkan Dinas Pendidikan dan sekolah sebagai implementor utama dan didukung serta dikoordinasikan dengan instansi lain dalam rangka mencapai keberhasilan yang diinginkan. Dapat dikatakan bahwa komunikasi dan koordinasi antar organisasi yang terkait dalam implementasi kebijakan berjalan dengan baik. (hasil wawancara, Juni 2020).

Selanjutnya, selain dari pada komunikasi dan koordinasi antar implementor kebijakan, pengetahuan masyarakat selaku kelompok sasaran juga diberikan dalam rangka mencapai sasaran kebijakan. (hasil wawancara, Juni 2020).

Sebagaimana menurut pendapat George Edward III dalam Deddy Mulyadi (2016:70) apa yang menjadi tujuan dan sasaran kebijakan harus disampaikan kepada kelompok sasaran sehingga akan mengurangi penyimpangan dalam implementasi. Tujuan dan sasaran yang tidak jelas bahkan tidak diketahui sedikitpun oleh kelompok sasaran, dapat menimbulkan resistensi dari kelompok sasaran.

Berdasarkan temuan peneliti dari hasil wawancara yang dilakukan pada Juni 2020, cara masyarakat selaku kelompok sasaran untuk mengetahui kebijakan dengan baik dapat diperoleh melalui sosialisasi. Pada implementasi kebijakan dalam PPDB dengan menggunakan sistem zonasi di Kota Padang, Dinas Pendidikan telah melakukan sosialisasi kepada pemimpin dalam masyarakat seperti Camat, Kepala Kelurahan, Kepala sekolah (SD), Kepala Komite (SD), dan kemudian mereka berkewajiban untuk mensosialisasikannya lagi ke masyarakat di daerahnya secara menyeluruh. Hal ini sesuai dengan Permendikbud Nomor 51 Tahun 2018 Pasal 40 poin a.

Selain sosialisasi, keterbukaan informasi atau transparansi juga menjadi hal yang penting dalam mencapai komunikasi dan koordinasi yang baik pada implementasi kebijakan. Sebagaimana menurut Nico (2007:20-21) bahwa tiap-tiap kebijakan yang diterbitkan oleh pelaksana kebijakan harus memberikan kesempatan yang luas bagi masyarakat untuk ikut berpartisipasi, dengan memberikan akses secara terbuka terhadap kebijakan tersebut.

Siswanto, dkk. (2016:53) juga mengemukakan bahwa transparansi dalam suatu kebijakan adalah dasar yang dapat menjamin keleluasaan bagi seluruh masyarakat dalam rangka mendapatkan informasi yang berkaitan dengan pelaksanaan pemerintahan, juga keterbukaan implementor dalam menciptakan kebijakan.

Berdasarkan temuan peneliti dari hasil wawancara yang dilakukan pada Juni 2020, Dinas Pendidikan Kota Padang menunjukan transparansinya dengan cara menyampaikan segala informasi terkait PPDB di website psb.diknaspadang.id. Hal ini sesuai dengan Perwako Padang Nomor 32 Tahun 2019 Pasal 5 ayat (2). Selain itu 
informasi juga disampaikan melalui papan pengumuman, spanduk dan brosur-brosur, hal ini sebagaimana Perwako Padang Nomor 32 Tahun 2019 Pasal 4 ayat (2) Sistem online dalam implementasi PPDB membuat informasi menjadi terbuka dan seluruh masyarakat dapat mengaksesnya.

Namun terkait informasi mengenai siswa yang tidak diterima beserta alasannya, Dinas Pendidikan memang tidak mengumumkan hal tersebut karena Dinas Pendidikan merasa pengumuman mengenai siswa yang diterima saja sudah cukup. (hasil wawancara, 27 Juli 2020)

Selanjutnya sekolah juga tidak mengumumkan soal alasan siswa tidak diterima karena seleksi PPDB dengan menggunakan sistem zonasi menjadi hak dan tanggungjawab Dinas Pendidikan yang dilaksanakan dengan memanfaatkan sistem online yang diatur secara otomatis untuk menyeleksi peserta didik berdasarkan kriteria kelulusan yang tertuang dalam Perwako Nomor 32 Tahun 2019. (hasil wawancara, 27 Juli 2020).

\section{4) Karakteristik Agen Pelaksana}

Implementasi kebijakan juga dipengaruhi oleh karakteristik dari para agen pelaksana, yakni sejauhmana para implementor mendukung pelaksanaan suatu kebijakan. Sebagaimana pendapat Van Meter dan Van Horn dalam Deddy Mulyadi (2016:72) yang menyatakan karteristik agen pelaksana yakni sejauhmana kelompokkelompok yang berkepentingan memberikan dukungannya untuk pelaksanaan kebijakan, juga karakter implementor yaitu menolak atau mendukung kebijakan.

Pada implementasi PPDB dengan sistem zonasi pada SMP Negeri di Kota Padang, Dinas Pendidikan sangat mendukung implementasi kebijakan karena mereka adalah pelaksana kebijakan. Walaupun pada awal kebijakan akan di implementasikan terdapat penolakanpenolakan yang timbul dari staf-staf yang terlibat dalam implementasi kebijakan. (hasil wawancara, Juni 2020).
Penolakan-penolakan dari staf yang terlibat dalam implementasi kebijakan di Dinas Pendidikan terjadi karena peraturan dari pusat yang mengatur secara umum tanpa mengkhususkan kondisi daerah tertentu yang akhirnya membuat staf yang bertanggungjawab bingung bagaimana cara agar kebijakan bisa tetap diimplementasikan dengan tetap memperhatikan kondisi daerah. Namun penolakan tersebut bisa diatasi dan tidak menjadi penghambat implementasi kebijakan. (hasil wawancara, Juni 2020).

Berdasarkan temuan peneliti di SMPN 17 Padang, SMPN 25 Padang dan SMPN 31 Padang, ketiga sekolah tersebut sangat mendukung implementasi kebijakan dalam PPDB dengan menggunakan sistem zonasi. Tidak ada penolakan dari seluruh staf yang ada di sekolah terkait implementasi kebijakan. (hasil wawancara, Juni 2020).

Selain dari dukungan implementor dalam implementasi kebijakan, dukungan dari publik atau masyarakat selaku kelompok sasaran juga menjadi hal yang penting. Sebagaimana menurut Van Meter dan Van Horn dalam Deddy Mulyadi (2016:72) yang menyatakan karteristik agen pelaksana termasuk karakter implementor yaitu menolak atau mendukung kebijakan, dan seperti apa bentuk opini masyarakat apakah mendukung atau menolak pelaksanaan kebijakan.

Berbeda dengan Dinas Pendidikan dan Sekolah yang sepenuhnya mendukung implementasi kebijakan, masyarakat justru terbagi menjadi dua golongan, yakni ada masyarakat yang mendukung dan juga ada masyarakat yang menolak implementasi kebijakan. (hasil wawancara, Juni 2020).

Penyebab masyarakat yang menolak pada umumnya adalah karena masyarakat atau orang tua calon peserta didik tidak terima jika anaknya tidak lolos di sekolah yang diinginkan, dan masih kuatnya pola pikir tentang sekolah yang dianggap unggul lebih baik dari sekolah pinggiran. (hasil wawancara, Juni 2020). 
Temuan ini didukung oleh penelitian Khairunisa Adinda dan Suyato (2019) yang menyatakan bahwa pola pikir orang tua yang menginginkan anaknya bersekolah di sekolah favorit atau unggulan belum dapat diubah dengan adanya sistem zonasi ini.

Penolakan dari masyarakat juga disebabkan karena orang tua calon peserta didik tidak terima jika anaknya tidak lolos di sekolah yang diinginkan walaupun sebenarnya calon peserta didik tersebut memiliki nilai yang lebih rendah dari calon peserta didik pendaftar lainnya. (hasil wawancara, Juni 2020).

\section{5) Kondisi Sosial, Ekonomi dan Politik}

Faktor lain yang mendukung keberhasilan pelaksanaan suatu kebijakan adalah keadaan sosial, politik dan ekonomi. Sebagaimana pendapat Van Meter dan Van Horn dalam Deddy Mulyadi (2016:72) yang menyatakan jika keadaan sosial, ekonomi dan politik bisa mendorong keberhasilan dalam pelaksanaan suatu kebijakan.

Keadaan sosial, tingkat perekomian dan tingkat pendidikan masyarakat berpengaruh terhadap implementasi kebijakan dalam PPDB dengan sistem zonasi pada SMPN di Kota Padang. Dukungan dan penolakan dari masyarakat dipengaruhi oleh keadaan sosial, dan ekonomi masyarakat yang berbeda-beda. Namun kondisi politik tidak berpengaruh terhadap berhasilnya pengimplementasian suatu kebijakan. (hasil wawancara, Juni 2020).

6) Disposisi Implementor

Van Meter dan Van Horn dalam Deddy Mulyadi (2016:72) menjelaskan jika disposisi implementor melingkup 3 aspek, pertama adalah bagaimana tanggapan para pelaksana akan adanya suatu kebijakan. Hal ini dapat mempengaruhi keinginannya dalam mengimplementasikan suatu kebijakan.

Temuan peneliti memberikan petunjuk bahwa pada umumnya, implementor kebijakan memiliki tanggapan yang baik terhadap adanya kebijakan ini. Mereka berpandangan bahwa kebijakan ini memiliki tujuan yang baik, sehingga seluruh implementor mengimplementasikan kebijakan sesuai dengan tugasnya masing-masing. (hasil wawancara, Juni 2020).

Hal kedua adalah pemahaman implementor terhadap kebijakan. Pada Dinas Pendidikan, pemahaman terkait kebijakan diberikan kepada staf yang terlibat dalam implementasi kebijakan dengan cara melibatkan mereka semua ke dalam setiap rapat terkait PPDB. Jika ada diantara mereka yang berhalangan untuk hadir dalam rapat, maka di lain kesempatan staf yang menghadiri rapat memberikan penjelasan terkait hal-hal yang dibahas dalam rapat. Sehingga seluruh staf yang bertanggungjawab paham terhadap kebijakan. (hasil wawancara, Juni 2020).

Sebagaimana Dinas Pendidikan, sekolah (SMP) juga membentuk tim khusus terkait pengimplementasian kebijakan, yang mana dalam memberikan pemahaman sekolah melaksanakan rapat panitia terlebih dahulu sehingga seluruh staf yang bertanggungjawab paham terhadap kebijakan. Setiap panitia mempunyai tugasnya masing-masing sesuai dengan porsinya. (hasil wawancara, Juni 2020).

Hal ketiga adalah intensitas dalam disposisi implementor, yaitu kecenderungan atau preferensi suatu nilai dari implementor kebijakan. Penulis memaknai intensitas disposisi implementor sebagai tingkatan kekuatan disposisi para implementor kebijakan. (Deddy Mulyadi, 2016:72).

Pada implementasi kebijakan PPDB dengan sistem zonasi pada SMP Negeri di Kota Padang, disposisi implementor dilaksanakan dengan pelimpahan kewenangan kepada bidang-bidang tertentu yang relevan dalam menangani PPDB dengan menggunakan sistem zonasi. Di Dinas Pendidikan Kota Padang, Kepala Dinas melimpahkan wewenang terkait implementasi PPDB dengan menggunakan sistem zonasi kepada UPTD Dapodik Dinas 
Pendidikan Kota Padang. (hasil wawancara, Juni 2020).

Temuan peneliti memberikan petunjuk bahwa tingkatan kekuatan disposisi para implementor pada implementasi kebijakan sudah baik. Hal ini ditinjau dari pengawasan terhadap implementasi kebijakan. (hasil wawancara, Juni 2020).

Pengawasan di Dinas Pendidikan Kota Padang dilakukan secara langsung oleh Kepala Dinas kepada staf yang terlibat dalam implementasi kebijakan. Selanjutnya disposisi dari Dinas Pendidikan ke sekolah yang juga berlaku sebagai implementor kebijakan dilakukan melalui pembentukan peraturan atau petunjuk teknis yang dapat dipedomani oleh sekolah dalam melaksanakan tugasnya. (hasil wawancara, Juni 2020).

Dalam pelaksanaannya Dinas Pendidikan melakukan pengawasan terhadap sekolah secara langsung dengan mendatangi atau menghubungi pihak sekolah maupun pengawasan secara tidak langsung melalui website PPDB. Hal ini sesuai dengan Perwako Padang Nomor 32 Tahun 2019 Pasal 37 (1). Selanjutnya untuk pengawasan di internal sekolah sendiri, Kepala sekolah juga melakukan pengawasan kepada tim yang bertanggungajawab terhadap implementasi PPDB.

\section{Faktor Penghambat Implementasi Kebijakan PPDB dengan Sistem Zonasi pada SMP Negeri di Kota Padang}

Sebagaimana telah diuraikan sebelumnya bahwa dalam mengukur faktor penghambat implementasi kebijakan penerimaan peserta didik baru dengan sistem zonasi, penulis menggunakan 4 faktor penghambat dalam implementasi kebijakan menurut Bambang Sunggono, (1994:149-153) diantaranya : (1) isi kebijakan; (2) informasi; (3) dukungan; dan (4) pembagian potensi.
1) Isi Kebijakan

Bambang Sunggono, (1994:149) menjelaskan bahwa belum jelasnya isi suatu kebijakan dapat menyebabkan gagalnya pelaksanaan suatu kebijakan, artinya tujuan tidak cukup rinci. Berdasarkan temuan peneliti, jika dibandingkan dengan sistem sebelumnya, dalam hal standar dan aturan pelaksanaan, PPDB dengan menggunakan sistem zonasi lebih jelas dan terperinci. Pada aturan sebelumnya, ketentuan tentang PPDB tidak terlalu diatur secara rinci. Adanya aturan dari pusat membuat peraturan di daerah lebih kuat acuannya dan membuat daerah mempunyai payung hukum yang jelas. (hasil wawancara, Juni 2020).

Apabila dibandingkan dengan sistem sebelumnya, dalam hal standar dan aturan, PPDB dengan sistem zonasi memuat penjelasan yang lebih lengkap. Dengan demikian dapat dikatakan bahwa isi kebijakan terperinci dan tidak menghambat implementasi kebijakan. (hasil wawancara, Juni 2020).

Bambang Sunggono, (1994:149) juga menyatakan bahwa kekurangan terkait sumber daya pembantu juga menjadi penyebab kegagalan pada implementasi suatu kebijakan. Contohnya, hal-hal yang terkait dengan tenaga, waktu dan biaya.

Pada implementasi kebijakan PPDB dengan sistem zonasi pada SMP Negeri di Kota Padang tahun 2019, ketersediaan sumber daya pembantu seperti sarana dan prasarana sesungguhnya belum cukup memadai. Masih ada diantara implementor yang ada di Dinas Pendidikan yang tidak mempunyai fasilitas perangkat komputer. Hal ini disebabkan karena anggaran yang tidak cukup untuk memperbaharui perangkat komputer. Kemudian dari segi kewenangan/keahlian staf yang bertanggungjawab terhadap implementasi PPDB dengan menggunakan sistem zonasi di Dinas Pendidikan dan sekolah juga belum sepenuhnya memadai. (hasil wawancara, Juni 2020). 
Namun kendala-kendala yang telah di kemukakan di atas tidak menjadi penghambat dalam implementasi kebijakan karena Dinas Pendidikan mengatasi faktor penghambat tersebut dengan cara mengoptimalkan anggaran dan sarana prasarana yang ada, dan memposisikan pegawai pada bidang yang sesuai dengan keahliannya masing-masing. Berdasarkan temuan peneliti tersebut dapat dikatakan bahwa kekurangan terkait sumber daya pembantu tidak menghambat implementasi kebijakan. (hasil wawancara, Juni 2020).

\section{2) Informasi}

Bambang Sunggono, (1994:150) mengemukakan bahwa dalam pelaksanaan suatu kebijakan, seharunya implementor yang terlibat memiliki informasi yang berkaitan dengan kebijakan dalam rangka berperan dalam implementasi kebijakan dengan baik, namun pada kenyataannya informasi tersebut tidak ada. Contohnya, dikarenakan terdapatnya gangguan komunikasi. Hal inilah yang menjadi penghambat pelaksanaan kebijakan.

Berdasarkan temuan peneliti pada implementasi kebijakan, komunikasi dan koordinasi antar implementor kebijakan cukup maksimal. Baik Dinas Pendidikan maupun sekolah tidak menemui kendala dalam hal komunikasi dan koordinasi. Sehingga tidak terdapat gangguan komunikasi yang menyebabkan terhalangnya informasi untuk tersampaikan. Komunikasi yang baik membuat kendala yang dihadapi di lapangan saat implementasi kebijakan berlangsung bisa diselesaikan dengan segera. (hasil wawancara, Juni 2020).

Selanjutnya selain dari informasi untuk pemegang peran dalam implementasi kebijakan, penyampaian informasi atau sosialisasi ke masyarakat selaku kelompok sasaran juga bisa saja mengalami kendalakendala yang dapat menjadi penyebab terhambatnya pelaksanaan kebijakan. Sebagaimana pendapat George Edward III dalam Deddy Mulyadi (2016:70) mengemukakan bahwa tujuan dan sasaran yang tidak jelas bahkan tidak diketahui sedikitpun oleh kelompok sasaran, dapat menimbulkan resistensi dari kelompok sasaran.

Berdasarkan temuan peneliti, sistem sosialisasi berjenjang yang dilakukan oleh Dinas Pendidikan dinilai belum cukup maksimal. Belum maksimalnya sosialisasi tersebut menyebabkan kurangnya pemahaman dan menyebabkan timbulnya resistensi dari masyarakat terhadap kebijakan. (hasil wawancara, Juni 2020).

Temuan peneliti lainnya juga menunjukkan belum maksimalnya sosialisasi disebabkan karena waktu terbitnya petunjuk teknis pelaksanaan PPDB dengan menggunakan sistem zonasi yang mendekati waktu PPDB harus berlangsung, sehingga sosialisasi juga dilaksanakan berdekatan degan waktu pelaksanaan kebijakan, dan menyebabkan sosialisasi yang dilaksanakan belum maksimal. (hasil wawancara, Juni 2020).

Temuan ini didukung oleh penelitian Khairunisa Adinda dan Suyato (2019) yang menyatakan sosialisasi sistem zonasi yang mendekati hari pelaksanaan PPDB menyebabkan kurangnya pemahaman dan membuat orang tua calon peserta didik bingung.

\section{3) Dukungan}

Bambang Sunggono, (1994:151) menyatakan bahwa pengimplementasian kebijakan yang tidak cukup memiliki dukungan akan menyebabkan kebijakan sulit untuk terimplementasikan.

Pada saat kebijakan PPDB dengan sistem zonasi pada SMP Negeri di Kota Padang tahun 2019 akan diimplementasikan, terdapat penolakanpenolakan dari staf yang terlibat dalam implementasi kebijakan di Dinas Pendidikan. Penolakan terjadi karena peraturan dari pusat yang mengatur secara umum tanpa mengkhususkan kondisi daerah tertentu yang akhirnya membuat staf yang bertanggungjawab bingung 
bagaimana cara agar kebijakan bisa tetap diimplementasikan dengan tetap memperhatikan kondisi daerah. Namun penolakan tersebut bisa diatasi dan tidak menjadi penghambat implementasi kebijakan. (hasil wawancara, Juni 2020).

Selanjutnya temuan peneliti memberikan petunjuk bahwa penolakan yang paling dominan adalah penolakan dari masyarakat selaku kelompok sasaran yang tidak mendukung adanya implementasi kebijakan. Penolakan yang timbul dari masyarakat terjadi karena PPDB dengan menggunakan sistem zonasi membuat pilihan sekolah menjadi terbatas sehingga memperkecil kemungkinan anak untuk lolos di SMP Negeri. (hasil wawancara, Juni 2020).

Temuan ini didukung oleh penelitian Umi Latifatul Khasanah (2018) yang menyatakan bahwa kritik terhadap kebijakan sistem zonasi adalah terbatasnya pilihan sekolah bagi calon peserta didik.

Berdasarkan temuan peneliti, penolakan dari masyarakat menjadi salah satu faktor penghambat implementasi kebijakan. Karena dukungan dari masyarakat selaku kelompok sasaran penting dalam implementasi kebijakan. Penolakan dari masyarakat membuat implementasi kebijakan yang harusnya bisa dilesesaikan dengan segera menjadi terhambat karena harus mengatasi penolakan-penolakan yang timbul terlebih dahulu. (hasil wawancara, Juni 2020).

\section{4) Pembagian Potensi}

Bambang Sunggono, (1994:151) penyebab yang berkenaan pada tidak tercapainya suatu implementasi kebijakan ditentukan juga oleh unsur pembagian potensi di antara implementor kebijakan. Pada keadaan ini, berkenaan dengan diferensiasi wewenang dan tanggungjawab implementor. Struktur organisasi implementor bisa menyebabkan timbulnya masalah jika dalam pembagian tanggungjawab dan wewenangnya tidak terlalu disesuaikan pada pembagian tugas, juga kurangjelasnya pembatasan. Pembagian tugas yang kurang jelas dapat menghambat implementasi kebijakan. Karena pembatasan-pembatasan yang kurang jelas dapat mempengaruhi pemahaman implementor kebijakan terhadap wewenang dan tanggung jawab yang harus di emban.

Berdasarkan temuan peneliti pada implementasi kebijakan, pembagian tugas sudah dilaksanakan secara jelas. Terdapat pembatasan yang jelas dengan dibentuknya kepanitiaan khusus PPDB. Seluruh staf ditempatkan sesuai dengan kemampuannya masing-masing. Hal ini menjadikan setiap staf yang terlibat memahami wewenang dan tanggungjawabnya dengan baik sesuai dengan porsinya masing-masing. Dengan demikian dapat dikatakan bahwa tidak ada faktor penghambat dalam hal pembagian potensi. (hasil wawancara, Juni 2020)

\section{PENUTUP}

Berdasar pada hasil penelitian juga pembahasan yang telah dijabarkan di atas, implementasi kebijakan dalam PPDB dengan menggunakan sistem zonasi dapat dikatakan cukup maksimal. Pemerataan pendidikan, penghapusan kastanisasi dan favoritisme sudah terlaksana, walaupun pola pikir masyarakat terhadap sekolah unggulan belum dapat berubah.

Adapun kesimpulan untuk lebih jelasnya dapat dilihat berdasarkan enam unsur dalam implementasi menurut Van Meter dan Van Horn, di antaranya standar dan sasaran kebijakan cukup jelas, terukur, dan dapat dipahami para implementor kebijakan, sehingga tidak menyebabkan konflik antar implementor kebijakan; Sumber daya manusia dan non manusia cukup memadai; Komunikasi dan koordinasi antar organisasi sudah berjalan dengan baik; Dinas Pendidikan dan sekolah mendukung implementasi kebijakan, sedangkan dari kalangan masyarakat ada yang menerima dan ada yang menolak kebijakan; Keadaan sosial dan ekonomi berpengaruh terhadap implementasi kebijakan, namun keadaan 
politik tidak mempengaruhi implementasi kebijakan; Seluruh staf yang terlibat mengganggap kebijakan dalam PPDB dengan sistem zonasi baik dan seluruhnya paham terhadap kebijakan; Pengawasan dalam implementasi kebijakan juga berjalan dengan lancar.

Selanjutnya mengenai faktor penghambat implementasi kebijakan di antaranya: Interpretasi yang menyebabkan konflik muncul dikalangan masyarakat, karena kurangnya dukungan dan pemahaman dari masyarakat; sistem sosialisasi berjenjang yang dilakukan oleh Dinas Pendidikan belum cukup maksimal; waktu terbitnya petunjuk teknis yang mendekati waktu PPDB harus berlangsung, sehingga sosialisasi belum maksimal.

Pemerintah perlu mempersiapkan diri secara matang jauh-jauh hari sebelum PPDB dilaksanakan, agar sosialisasi kepada seluruh staf yang terlibat dalam implementasi dan sosialisasi kepada masyarakat bisa tercapai secara menyeluruh.

\section{DAFTAR KEPUSTAKAAN}

Aldri, dkk. 2011. Kebijakan Penanggulangan dan Pembinaan Anak Jalanan di Kota Padang. [Laporan Hasil Penelitian]. Padang (ID): Universitas Negeri Padang.

Bambang Sunggono. 1994. Hukum dan Kebijaksanaan Publik. Jakarta: Sinar Grafika.

Deddy Mulyadi.2016. Studi Kebijakan Publik dan Pelayanan Publik: Konsep dan Aplikasi Proses Kebijakan Publik Berbasis Analisis Bukti untuk Pelayanan Publik. Bandung : Alfabeta.

Eko Handoyo. 2012. Kebijakan Publik. Semarang:Widya Karya.

Khairunisa Adinda dan Suyato. 2019. Dampak Kebijakan Zonasi pada Penerimaan Peserta Didik Baru di
SMAN 3 Yogyakarta dan SMAN 7 Yogyakarta. Jurnal Pendidikan Kewaraganegaraan dan Hukum Vol. 8 No.8.

Kompas.2018. Alasan Kemdikbud Jalankan Sistem Zonasi. [internet]. [diakses 4 Agustus 2019]. Tersedia pada: https://edukasi.kompas.com/read/2018 /06/05/22040311/ini-alasankemendikbud-jalankan-sistem-zonasi.

Nico Adrianto. 2007. Transparansi dan Akutanbiitas Public melalui eGonerment. Malang: Bayumedia Publising.

Peraturan Menteri Pendidikan dan Kebudayaan Republik Indonesia Nomor 51 Tahun 2018 tentang Penerimaan Peserta Didik Baru pada Taman Kanak-kanak, Sekolah Dasar, Sekolah Menengah Pertama, Sekolah Menengah Atas, dan Sekolah Menengah Kejuruan.

Peraturan Walikota Padang Nomor 32 Tahun 2019 tentang Tata Cara Pelaksanaan Penerimaan Peserta Didik Baru.

Siswanto, dkk. 2016. Pengaruh Transparansi Kebijakan Publik Terhadap Pengetahuan Dewan Tentang Anggaran dengan Partisipasi Masyarakat Sebagai Variabel Moderasi. Jurnal Kajian Ekonomi dan Keuangan Daerah. Vol.1, No.2.

Sri Suwitri.2014. Analisis Kebijakan Publik. Jakarta: Universitas Terbuka.

Umi Latifatul Khasanah. 2018. Implementasi Kebijakan Sistem Zonasi Perspektif Stakeholder Sekolah. [tesis]. Malang (ID): Universitas Islam Negeri Maulana Malik Ibrahim Malang. 